Section Editors

David C. Spencer, MD

Steven Karceski, MD

David C. Spencer, MD

\title{
The neurology world is flat
}

Thomas Friedman, in his 2005 book The World is Flat, explained that a combination of progress in technology, transportation, and economic forces has accelerated "globalism." Globalism means that our once-distant neighbors in the worldthose in faraway countries - are no longer that far away. Our wealth, peace, health, and well-being are all tied together. Because of this, health problems throughout the world cannot be so easily ignored as in the past. In some areas of the world, especially in Africa, the ability of people to get good health care for neurologic problems or diseases receives less attention than other global health problems.

Johan Aarli and his co-authors discuss neurologic care in Africa in their article "Neurology in sub-Saharan Africa: A challenge for World Federation of Neurology."2 Publication of this article reflects the increasing attention that the journal Neurology ${ }^{\circledR}$ is paying to global health issues. Sub-Saharan Africa (SSA) is the part of Africa that is south of the Sahara Desert and contains many of the poorest or "developing" countries in the world. Developing countries have widespread poverty, high birth rates, poor economy, and most often depend on other countries for financial support.

Dr. Aarli and coworkers discuss the problems in SSA, ways to improve the situation, and plans that are already in place.

WHAT IS HAPPENING WITH NEUROLOGIC CARE IN SUB-SAHARAN AFRICA? Dr. Aarli and his co-authors note that sub-Saharan Africa has become the poorest area in the world, and those who live in this area receive very limited neurologic care. While Western Europe has approximately one neurologist for every 20,000 people, all of Africa has one neurologist for every 3 million people.

The problems in SSA involve all aspects of health care, including very few trained nurses, few services to diagnose and treat illnesses, few training programs, and poor access to drugs to treat illness. Another important problem affecting neurologic conditions is that there are no use- ful disability programs. These are programs that help those who have an illness to cope or receive care. Most countries in the region do not have a health care system where the government pays for care, and nearly all medical costs are paid by the patient. This situation makes it even harder for most people to get care for neurologic problems.

WHAT AREAS OF NEUROLOGY NEED THE MOST ATTENTION? WHICH PROBLEMS ARE MOST EASILY SOLVED? The authors discuss specific disorders and diseases that are not getting enough attention. Some of these conditions are similar to those seen in wealthier countries. For example, epilepsy, a common problem throughout the world, is seen even more in developing countries, with about $85 \%$ of cases occurring in those countries.

The direct medical effects of seizures are a major source of disability. Also, the stigma people with epilepsy go through is a problem throughout the world but is worse in the developing world, adding to their loneliness and disability. There are low-cost medications to treat epilepsy (for example, phenobarbital costs about \$5 US/year), which shows that much could be done with little money.

Infectious disease affecting the brain or nervous system, much of which can be treated or prevented, affects millions in SSA. For example, 64\% of new HIV infections are in SSA, and about onethird to two-thirds of these individuals will develop neurologic problems.

Even though stroke is common in the developed world, the authors state that two-thirds of strokes and $90 \%$ of stroke deaths occur in developing countries. A large number of deaths from stroke occur in developing countries, probably because there are few trained specialists, little help for rehabilitation, and poor social support systems. Many deaths from neurologic disease in SSA can be prevented.

Dr. Aarli and coworkers note that simply counting the number of deaths from neurologic disease underestimates the problem. The effect of neurologic conditions is more often felt in "lost 
years of healthy life" and in loneliness because of stigma.

WHAT IS THE ROLE OF PREVENTION? Dr. Aarli and coworkers identify prevention as an important component of health promotion efforts in SSA. Prevention efforts can limit the development of neurologic problems in many ways. Vaccination programs can prevent infectious disease. Other programs might be able to rid the region of other infectious diseases such as malaria and river blindness. Traffic safety efforts could reduce the problems with brain injury from accidents. Many of these efforts depend on the development of complete systems of primary health care and the efforts of leaders in the health care system. If officials from government, nongovernmental agencies, and international organizations work together, some of the problems will be solved.

WHAT IS BEING DONE? The World Federation of Neurology (WFN) is an important organization that deals with global neurology issues, and the efforts of this group are the focus of the article by Dr. Aarli and co-authors. In 2006, the WFN created a plan for the future of neurology in Africa. They did this with help from neurologists in Africa. By the end of 2007, a WFN Africa committee made up of African neurologists will begin working together. Their first steps will be to organize, including gathering a list of neurologists in Africa. They also hope to increase the training of neurologists in Africa by 10 per year and expand the number of training programs on the continent.

If local training improves, this may help the problem of "brain drain," which occurs when African physicians who get medical training in another country do not return to Africa.

Examples of specific steps to improve the problems have included donations of educational materials and training funds from the American Academy of Neurology and the Japan Neurological Society. New programs including visits of US neurologists to Zambia, providing neurology guidebooks for nonphysician health workers, and "neuro caravans" (travel of neurologists from large cities to other regions for giving care and training of health care workers) are in place or planned. The WFN would like other organizations to follow their lead.

CONCLUSIONS Neurologic care in SSA needs to be better. Governmental, nongovernmental, and international groups must work together. If public health and primary care systems are put in place and combined with efforts to improve neurologic care, there may be great success in improving these problems in SSA. The World Federation of Neurology hopes to be at the center of these efforts.

\section{FOR MORE INFORMATION}

World Federation of Neurology http://www. wfneurology.org/index.htm

\section{REFERENCES}

1. Friedman T. The world is flat. New York: Farrar, Straus and Giroux; 2005.

2. Aarli JA, Amadou GD, Lochmüller H. Neurology in sub-Saharan Africa: a challenge for World Federation of Neurology 2007; 69:1715-1718. 


\section{Neurology}

The neurology world is flat

David C. Spencer

Neurology 2007;69;E16-E17

DOI 10.1212/01.wnl.0000289578.20018.ef

This information is current as of October 22, 2007

\section{Updated Information \&}

Services

Permissions \& Licensing

Reprints including high resolution figures, can be found at: http://n.neurology.org/content/69/17/E16.full

Information about reproducing this article in parts (figures,tables) or in its entirety can be found online at:

http://www.neurology.org/about/about_the_journal\#permissions

Information about ordering reprints can be found online:

http://n.neurology.org/subscribers/advertise

Neurology ${ }^{\circledR}$ is the official journal of the American Academy of Neurology. Published continuously since 1951, it is now a weekly with 48 issues per year. Copyright . All rights reserved. Print ISSN: 0028-3878. Online ISSN: 1526-632X.

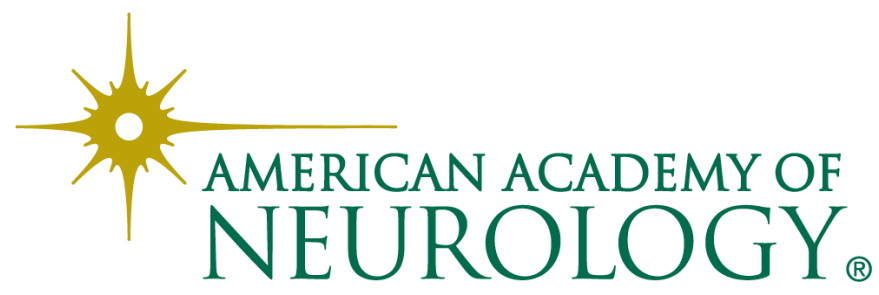

